\title{
EFFECTS OF THE GEZI PARK MOVEMENT ON RENEWAL OF THE DEMOCRATIZATION DEBATE IN TURKEY
}

\begin{abstract}
The text presents the history of attempts at democratization of the political system in Turkey, where despite the nominal presence of democratic institutions, changes traditionally have come from the top. Following a brief presentation of the unsuccessful civil movements from the 1970s onwards, it focuses on the 2010s transition in approaches to building democratic culture, and in particular on the Gezi Park resistance, where a relatively minor local issue sparked a country-wide citizens' protest against the conservative democracy of the ruling AK Party. The event is shown as an entirely new type of protest, a spontaneous civil movement with horizontal structure, inspired by the Occupy movements, and an expression of the new generation's approach to politics. It also gave rise to a movement which contributed to rethinking the Turkish democratization process by breaking with the established thinking with a bottom-to-top approach.
\end{abstract}

\section{Key words}

Turkey, democratization, grass-roots movements, civil society, Gezi Park

* Faculty of Economics and Administrative Sciences, Niğde Ömer Halisdemir University, Turkey, e-mail: yavuzy82@gmail.com 


\section{Introduction}

Historically and conceptually, Turkish democratic tradition does not easily compare to the traditional Western concepts of democracy. Turkey does not have a typical liberal democracy; however, it reflects its deficiencies. The efforts to establish some basic institutions such as an assembly, constitution and legitimizing the law system during the late Ottoman era were not successful for many reasons, but especially because of the absence of popular demand. At the beginning of the new Turkish Republic in 1923, the overlapping of the founding party (CHP) and state undermined the concept of the rule of law. The constant conflict between the state-elites and political elites has shaped Turkey's political identity (Kadıŏlu, 1998, p. 189).

The agricultural economy and underdeveloped structure of the Turkish economic system has affected the establishment of social classes. Therefore no grass-roots movement, from the classical liberal or class-perspective, initiated any changes in the political system. The rule of law is also restricted by the "necessities of the state", or in other words "the survival of the state" which is decided upon by the top authorities. This is also similar to the operation of civil society which does not operate bottom-up, but again the influence is top-down and state-oriented. 'The state valued in its own right, is relatively autonomous from society' and there is a suspicion of pluralistic ideas being adapted (Özbudun, 2000, pp. 128-129). The debates over the concepts of democracy and civil society have little heritage of being opposed in a critical framework. In this context Turkish grass-roots movements are labeled as evil by the state and are rarely organized. Generally, institutional and state-related concepts in the struggle for control of civil and political power take precedence.

The main aim of this study is to underline the failure of Turkish social movements to shape the democratic culture of the country; it focuses on the Gezi Park resistance as an exceptional experiment countering this situation. This event gave rise to a movement that has helped to rethink the Turkish democratization process. Historically, changes have come from top-to-bottom, while the Gezi Park movement broke with this established thinking with a bottom-to-top approach. This was not a sudden shift but much more of a transition in the expression of democratic demands in Turkey. 
Before the Gezi Park resistance, there were some other movements which affected the agenda in the early 2010s such as the TEKEL workers' resistance in Ankara against their union's decision to collaborate with the government, as well as the HES resistance which opposed building hydroelectric plants. These were the first steps of a new type of opposition to emerge outside of the institutional bodies. Therefore Turkish movements were influenced for a few years by the changing dynamics of similar movements on a global level. This process started at the beginning of the 2000s with the anti-globalization movement taking place in different parts of the world, especially in Latin America. More recently, Turkey embraced this kind of new opposition approach and joined the democracy debates that were taking place worldwide. It was thanks to the Gezi Park initiative that Turkey joined movements which criticized the institutions of a market-oriented and limited democracy of this neoliberal era. Turkish people understand the power and importance of taking to the streets and public spaces to affect the decision-making process. Following the Gezi Park resistance, public authorities as well realize the power of such movements and difficulties in resisting them.

Some of the major turning points of social movements were the "new social movements" of the 1970 s and the "alter/anti-globalization movements" that began in the 2000s. The more recent popular mobilizations of the Occupy and the Gezi Park have some similarities as well as differences, but in general they opposed a neoliberal worldview and today they symbolize a critical view on neoliberalism from both economic and political perspectives. This also indicates the connections between West/North (the more liberal democratic countries) and East/South (more non-typical democracies). The common denominator of the latest movements is that they are both critical towards liberal democracies under the domination of neoliberal policies. As a country that is geographically and culturally stuck between East and West, Turkey did not integrate with the earlier movements of the 1970s and 2000s. However, as Turkey's position on the global market has changed in recent years, the effects of the local movements have gained importance in resisting the market-based politics.

While Occupy movements clearly expose the injustices of the neoliberal economic system, the Turkish Gezi Park movement also highlighted the lack of a democratic approach which was solidly set in Turkish government policies and politics. Turkish politics had not been confronted by democratic demands that are supported by a grass-roots movement since the 1970s, which has made participation in the political process very limited since the 1980 military coup. Although Turkish grass-roots movements have not been able to radically change 
the democratic processes of the Turkish government, the Gezi Park movement created a challenge in the discourse of Turkish democracy by the direct action of common citizens in public areas which influenced the decision-making process that reached beyond the elections.

\section{A Short History of Turkish Movements}

After the 1980 military coup, all opposition movements, political organizations and parties were banned in Turkey. The new regime was established opposing the democratic period of the 1960s and 1961 constitution that gave basic rights to organizations and made room for socialist ideas. 'The rigid suppression of any opinions which opposed their regimented and solidarist view of society' was the basis of the 12 September Regime (Hale, 2013, p. 269). This period marked the beginning of the neo-liberal security establishment. For the following ten years, economic liberalization continued in a gradual manner with the absence of any opposition movements. Political liberalization developed much slower than economic liberalization. Free elections were established beginning in 1983; however, they were under the control of the military. New political parties were established and a president elected during this period. During the latter half of the 1990s Turkey witnessed the growth of civil society's voice and a movement against "inner-state" or what were called "mafia-state-political" connections. The earliest connected grass-roots movement of the 1990s bore the slogan "one minute darkness for permanent enlightenment". The related action was people switching off their home electricity at a predesignated time to protest these antidemocratic relationships.

Bottom-up organizations gained importance during the process of tightening bonds with the European Union. Much like the revolution concept of the 1960s, civil society was involved in the democratization process, but this time it had a much more liberal connotation. According to Tilly (2004), democracy and social movements support each other. In different words, democratization is a result of social movements which had a chance to lead to democratic society. During the 1990s, especially regarding freedom of speech, human rights and freedom of organizations to operate, Turkish movements had an effect on the public agenda.

At the same time, Islamic movements played an important role; especially after the 1995 they gained power through elections, and the issue of women wearing headscarves became one of the main debates on the Islamic agenda. 
Islamic movements used daily life interactions successfully and their engagement with some newspapers and civil society organizations confirmed the agenda in their own way. Also the Kurdish movement, or at least their unarmed political parties, had an impact especially on the issue of human rights. Since 1980 the socialist parties lost their leading role, but new political parties such as the ÖDP (Özgürlük ve Dayanışma Partisi - the Freedom and Solidarity Party) were established in a renewal of discussions. However, their effect on setting political agenda was much lower than that of other cultural movements. Because of ÖDP's rank-and-file hierarchy and old school politics, a new kind of political debates has occurred horizontally, and somewhat anarchist tendencies have gained in importance. Especially at the beginning of the 2000s, anti-war and environmental movements have come forth with a new political agenda. The old-school parties and unions did not bring these issues forth publicly, and new movements that combine cultural and economic issues have caught the attention of young people. Gezi Park resistance was a specific case of this change, which will be discussed later in more detail.

Starting in the latter half of the 1990s, Turkish social movements converged in the terms of social movement approaches to affect the governmental policy processes. Citizens' daily life and life-style matters became one of the main points of the movements, and the civil society debates changed the face of politics by the wide-range of agendas represented by the movements. New struggles occurred opposing the crisis of institutional politics, and these movements started to affect agendas of public opinion especially in TEKEL and HES resistances (Yildırım, 2013).

\section{What Happened at Gezi Park?}

Gezi Park is located in Taksim, in the heart of Istanbul, Turkey's largest city. The government made a decision to turn this public park into a private sector to be used in an urban transformation project. Several young environmentalists began to guard trees in the park at the end of May 2013. Following a harsh intervention by police in the early morning hours, the young activists were taken from the Park and their tents burned. These actions created a public outcry and further protests via Twitter and Facebook; a large crowd held a protest against the police in the Park. The police intervened brutally once again, but the number of protesters continued to rise. What started as a protest soon turned into an occupation of the Park. Barricades were set up inside the park against the police, 
and those who gathered there created an autonomous space. Erdogan's speech against the movement and labeling the activists as "çapulcu" (looters) further raised anger and increased the number and solidarity of activists.

Although a horizontal initiative called Taksim Dayanışması (Taksim Solidarity) tried to get different NGOs to organize joint actions, it did not play a central role in the developing events. The subject of the movement was the anger of ordinary citizens against the government's actions. Those involved mobilized in a sporadic manner. The Gezi Park resistance was a grass-roots movement similar to the anti/alter-globalization movement and had a horizontal hierarchy. Those involved were searching for a new and "real" democracy and opposed the neoliberal markets (Roos, 2013). In spite of the continued harsh police interventions and constant pressure of the government to stigmatize the protestors' actions, the latter refused to give up and leave the park. This local resistance soon shifted to a national movement in different cities that criticized the Turkish form of democracy in general. The slogan of the resistance was, "It was not just about the trees". They developed a new ironic language, established new common places such as kitchens and libraries, and created a new vision of the future involving close connection between personal and public liberties. Later, park forums were established to continue the discussion about the process of what they can all do together.

Most Gezi movement activists were born in the 1990s, so they grew up under the AKP rule and were not related to the former opposition movements, nor were they members of a specific party or union. Young people born after 1980 were called "apolitic" or "uninterested in politics" by the older generation. However, they demonstrated a new kind of politics with their resistance against the police and created a new line of opposition. Two of their slogans became their rally cry - "This is just beginning, keep on with the struggle" and "This was not about the trees, don't you understand?".

The Gezi solidarity movement brought together people from a broad political spectrum. The protests spread to other cities, and the anti-AKP protests turned many people into street activists. As indicated earlier, in general, Turkish people did not take part in demonstrations and street riots, but many came into the streets, showing strong resistance against the government. Bayat commented on the transition of a passive network to an active network: 'Street as a public space has intrinsic feature that makes it possible for people to become mobilized through establishing passive networks' (Bayat, 2010, p. 63). The threat of the AKP to the social and public life of the ordinary people made a passive network of those who were anti-AKP 'turn into an active communication and cooperation', 
and those people attempted to abandon such social and economic arrangements, seeking alternative and more familiar, or informal, institutions and relations (Bayat, 2010, p. 63).

The resistance turned into indignation towards the conservative democracy of the ruling AKP. The changing dynamics of Turkish society were reflected by the resistance. Gezi Park resistance turned into an Occupy movement by staying there and connecting other places and people (Gambetti, 2014, p. 91). So Gezi Park was not a temporal collective action; rather it had a social movement nature with its influence reaching from daily life to the political process. In this process individuals tried 'to become subjects of their own lives' (Farro and Demirhisar, 2014). In other words, the reaction of the grass-roots uprising means people claimed agency in their own lives and their say in the decision-making process. The direct actions of the movement reminded the establishment of the power of the crowds of people and defended forgotten democratic values. Social movements are moving closer to a framework of anarchism that focuses on practicing direct action.

The Gezi Park uprisings were a concrete step towards trying to establish something new. It was resistance to transformation of an open space to a private area and resistance to the government transforming life in a neoliberal and conservative way (Özkırıml1, 2014, pp. 1-7; Rodriguez, Avalos, Y1lmaz \& Planet, 2013, pp. 420-421; Yildırım, 2014). It was not a typical socialist revolutionary or liberal civil disobedience action, but it rather displayed an anarchist tendency much like the Occupy movements (Gibson, 2013) with rejection of all established political parties of both the ruling and opposition wings. It is an ongoing and developing political attitude since the anti/alter globalization movement. Graeber (2002) labeled them as the "new anarchists". Their focusing on direct action and absence of organized structures make them closer to the anarchist discourse. They create new urban movements that use the cities' open spaces to make political and economic debates in a new manner. As Harvey (2012) argued, the struggle in cities is related to anti-capitalist movement, (pp. 161-162) and the different movements all around the world '[show] us the collective power of the bodies is still the most effective instrument of opposition when all other means of access are blocked'. 


\section{Making Sense of Gezi Park in Democratization}

The resistance has underlined a new democratic perspective. As the latest works of David Harvey (2012) and Manuel Castells (2012) show, the liberal democracy is criticized by actions in the streets of the cities and, as Hardt and Negri's report (2004), the multitude created a new common force. These efforts mean that citizens want to regain the right to govern directly. The limits of representative democracy begin here. In the 2000s, elections cannot be the only means for democratic debates. The masses are always a threat for both liberals and conservatives who try to control them in numerous ways, but in this new century such methods can no longer be easily accepted by the people who globalize the opposition movements through communication. They create a new public awareness that is common both in the streets and on the internet. The opposition exposes all sides of the problem, both cultural and economical. The new movements of this century reflect this multidimensional process.

Both Occupy movements and the Gezi Park resistance tried to change the way daily life is controlled and to create means to find a new solution. This means to go outside the liberal democracy and return to the roots of democracy as a public power. As Hardt and Negri (2004) said, it can be an "exodus" that is an escape route out of the established system.

Gezi Park was an extraordinary experiment for Turkey because of its direct action. This was not a fully anarchist movement nor a typical revolutionist or civil disobedience movement. Occupy movements have also experienced an anarchist attitude. The Gezi Park movement happened without old concepts such as leadership or a political party. It was also against the representative bodies. People represented themselves in open and public spaces and spoke for themselves. Turkish leftist organizations were not able to lead this movement, so it was a fully grass-roots uprising. With the inspiration of the Occupy movement, which is a resistance to the privatization of the public spaces, the Gezi Park resistance took the "occupy" label. This indicates a change in the history of Turkish movements in terms of adopting a new social movement approach. These movements can be seen as the second wave of the anti/alter-globalization movement with raising outrage against neoliberalism.

In the context of contentious politics, for Tilly and Tarrow (2007) the Occupy Gezi can be understood as 'sustained claim making, using repeated performances that advertise that claim, based on organization, networks, traditions and solidarities that sustain these activities'. It could not change the government, but as a social movement campaign 'challenged to power holders in the name of 
a population living under the jurisdiction of those power holders'. However, beyond the structural analysis of contentious politics it has similarities to Occupy movement's anarchist tendencies and to a new type of social movements that combine cultural and economic debates. In general, to understand both Occupy and Gezi Park social movements' approaches, the citizens' daily life must be considered a great part of grass-roots movements because they constitute a new type of political force outside the established institutional politics and representative democracy.

The resistance was against the ruling style of conservative government that ignores the rule of law and is quick to intervene in people's daily lives. It can be said that the resistance was a defense of the heart of public life. It can also be argued that it was a revival of the spirit of the earlier movements of '68 as well as the 2000s for Turkey. It could also be considered as an echo of Occupy movements and the Arab Spring in Turkey. In both these examples people tried to express themselves without representation and make political debate in public and open places. It can be called a second wave of the worldwide anti-globalization movement. While Turkish movements did not connect with the first wave of the Seattle and Genova protests, they were affected by new demonstrations and learned from their actions.

Gezi Park movement was the most important step towards connecting Turkish movements with global ones. While Occupy movements gained popularity during several years in the larger cities like New York, London and Frankfurt and have more concrete demands, Gezi Park has wide-range grievances or demands and different discourses to renew the established-political culture of Turkey. In different cases these occupation movements can be seen as a new era of the anti-globalization movements that have been looking for a new political and public space. Turkish movements did not coincide with the movements at the beginning of the 2000s, but a major turning point was the summer of 2013. Unfortunately, the Turkish institutional opposition bodies did not take into account or analyze the new global movements such as $15 \mathrm{M}$, Indignados and Occupy. Thus they were surprised when the Gezi Park resistance exploded. However, there was a symbolic change of social movements worldwide as well as for Turkish people searching more democracy outside the officially established forms. Therefore this new century of movements will focus on democratic debate and criticism of the neoliberal, conservative or corporate versions. Turkish movements also will be affected by this process and, like in Gezi Park, people will speak through their movements directly, not just in elections. 


\section{Conclusion}

This resistance was a type of opposition movement of the 2000s that created 'unity in diversity' (Roos, 2013). It was an echo of the anti-globalization movement and similar types of movements that occurred around the world. There was no institutional support, no common manifestation or leading party, but instead shared beliefs and a commonly voiced "no" against the government was what mobilized ordinary people. This opposition to policies of the government towards daily life united the masses. This unexpected action is affected by the counter-globalization movement's opposition style, which does not match the institutional civil society activities of the 1990s. Instead of having a formal rankand-file procedure, the new movements of the 2000s revitalized the spirit of ' 68 by using new means of communication. It is related to disconnecting from the establishment of the institutional politics that make the formal framework of civil society. It was also an effort to change civil society's borders delineated by the government and the state. It can be said that it was not to be understood by liberal theory nor in the classical socialist way. Its demands of political liberalization are closer to anarchist tendencies that go beyond liberal and socialist approaches.

With the Gezi Park resistance, the voice of ordinary people who demand much more democracy became visible. This movement is directed towards changing how Turkey is organized from top-to-bottom, expanding the issues and involving active participation of citizens. It can be said that Turkish struggles such as Gezi Park converge with the global opposition movements. These changes will also affect Turkish politics as a whole, as both opposition parties and the governments will be more careful to take into account the demands of the grass-roots movements because liberal and representative democracies are under pressure of social movements to change established political borders, and Turkey cannot remain outside this tide. The popular demands of democracy strive to affect the decision making process, and the criticism of the privatization of public life under neoliberal values is raised by social movements. These efforts constitute a new form of politics which puts pressure on the liberal democratic system. Gezi Park created a social movement to criticize not only the ruling party but the whole of Turkish democracy. 


\section{REFERENCES}

Bayat, A. (2010). Life As Politics: How Ordinary People Changed Middle East. Stanford: Stanford University Press.

Castells, M. (2012). Network of Outrage and Hope: Social Movements in the Age of Internet. Cambridge: Polity Press.

Gambetti, Z. (2014). Occupy Gezi as the Politics of Body. In U. Özkırımlı (ed.), The Making of a Protest Movement in Turkey \#occupygezi. New York: Palgrave Pivot.

Graeber, D. (2002). The New Anarchist. New Left Review, 13:6, 61-73.

Hale, W. (2013). Turkish Politics and the Military [Kindle version]. Routledge. Retrieved from http://www.amazon.com

Hardt, M. \& Negri, A. (2004). Multitude: War and Democracy in the Age of Empire. New York: Penguin Press.

Harvey, D. (2012). Rebel Cities-From Right to the City to the Urban Revolution. London: Verso.

Kadıoğlu, A. (1998). The Paradox of Turkish Nationalism and the Construction of Official Identity. In S. Kedourie (ed.), Turkey: Identity, Democracy, Politics [Kindle version]. Routledge. Retrieved from http://www.amazon.com

Gibson, M.R. (2013) The Anarchism of the Occupy Movement. Australian Journal of Political Science, 48:3, 335-348. Retrieved on June 20, 2014 from DOI: 10.1080/ 10361146.2013.820687

Özbudun, E. (2010). Contemporary Turkish Politics: Challenges to Democratic Consolidation. Boulder, CO: Lynne Riener Publishers.

Özkırımlı, U. (2014). Introduction. In U. Özkırımlı (ed.), The Making of a Protest Movement in Turkey \#occupygezi, Palgrave Macmillan [e-book]. Retrieved from https:// www.palgrave.com/us/book/9781137413772.

Rodriguez, C., Avalos, A., Yılmaz, H. \& Planet, A. I. (2013). Some Observations on Turkey's Democratization Process. In C. Rodriguez, A. Avalos, H. Yilmaz \& A. I. Planet (eds.), Turkey's Democratization Process [Kindle edition]. Routledge. Retrieved from http://www.amazon.com

Roos, J. (2013, June 03). The Turkish Protests and the Genie Of Revolution Retrieved on June 20, 2014 from http://roarmag.org/2013/06/tahrir-taksim-egypt-turkey-protestsrevolution/

Tilly, C. \& Tarrow, S. (2007). Contentious Politics, Boulder, CO: Paradigm.

Tilly, C. (2004). Social Movements:1768-2004. Boulder, CO: Paradigm.

Yildirım, Y. (2013). An Analysis of the Tekel Resistance at Turkey in the Context of Social Movements. European Scientific Journal (ESJ), 9(26), 18-35.

Yıldırım, Y. (2014) The Differences of Gezi Parki Resistance in Turkish Social Movements, IJHSS, Vol. 4, 5(1), 177-185. 